attempts to explain the variation of bond lengths in terms of electronic effects due to the partial double bond character of $\mathrm{C}(7)-\mathrm{O}$.

Table 5. The shorter intermolecular contacts $(\AA)$ excluding hydrogen atoms

Symmetry code

(i)
(ii)
(iii)
(iv)

$$
\begin{array}{rrr}
\frac{1}{2}-x, & -y, & \frac{1}{2}+z \\
\frac{1}{2}+x, & \frac{1}{2}-y, & -z \\
\frac{1}{2}+x, & -\frac{1}{2}-y, & -z \\
1-x, & \frac{1}{2}+y, & -\frac{1}{2}-z
\end{array}
$$

\begin{tabular}{|c|c|c|}
\hline$C(23) \cdots C\left(17^{1}\right)$ & $3 \cdot 50$ & $C(10) \cdots C\left(23^{i i i}\right)$ \\
\hline$C(9) \cdots C\left(3^{i 1}\right)$ & $3 \cdot 54$ & $C(8) \cdots C\left(3^{i 1}\right)$ \\
\hline$C(9) \cdots C\left(2^{i 1}\right)$ & 3.55 & - $C\left(20^{i 1}\right)$ \\
\hline$C(3) \cdots C\left(19^{i i}\right)$ & $3 \cdot 57$ & $C(21)$. \\
\hline$C(3) \cdots C\left(20^{i i}\right)$ & $3 \cdot 61$ & $\cdot C\left(18^{i i}\right)$ \\
\hline$C(23) \cdots C\left(18^{1}\right)$ & $3 \cdot 64$ & $C(9) \cdots C\left(20^{1 i}\right)$ \\
\hline$C(8) \cdots C\left(2^{i i}\right)$ & 3.65 & \\
\hline
\end{tabular}

(iv)

The crystal packing is shown in Fig. 2, and the shorter intermolecular contact distances, excluding those involving $\mathrm{H}$ atoms, are in Table 5. None of these is shorter than the sum of the van der Waals radii. Contact distances involving the $\mathrm{I}^{-}$ion are all greater than $4 \AA$.

I thank Dr A. Yoshida for supplying the crystals, Professors J. C. Tatlow and J. C. Robb for their interest in this work, and the University of Birmingham for funds to purchase the diffractometer.

\section{References}

Bucourt, R. (1974). In Topics in Stereochemistry, Vol. 8. Edited by E. L. Eliel \& N. L. Allinger. New York: Interscience.

Ernst, S. R. \& Cagle, F. W. JR (1973). Acta Cryst. B29, $1543-1546$.

Gopalakrishna, E. M. \& Cartz, L. (1972). Acta Cryst. B 28, 2917-2924.

GuY, J. J. \& Hamor, T. A. (1974). Acta Cryst. B30, 22772282.

GuY, J. J. \& Hamor, T. A. (1975). J. Chem. Soc. Perkin II, pp. 1074-1078.

Hamilton, W. C. (1965). Acta Cryst. 18, 502-510.

Hamodrakas, S., Geddes, A. J. \& Sheldrick, B. (1974). Acta Cryst. B30, 881-886.

Hamor, T. A. (1976). J. Chem. Soc. Perkin II. To be published.

Hanson, H. P., Herman, F., Lea, J. D. \& Skillman, S. (1964). Acta Cryst. 17, 1040-1044.

International Tables for X-ray Crystallography (1962). Vol. III. Birmingham: Kynoch Press.

Klyne, W. \& Prelog, V. (1960). Experientia, 16, 521.

Kneale, G., Geddes, A. J. \& Sheldrick, B. (1974). Acta Cryst. B30, 878-881.

Stewart, J. M., Kruger, G. J., Ammon, H. L., Dickinson, C. \& HALl, S. R. (1972). The X-RAY System - version of June 1972. Technical report TR-192 of the Computer Science Center, Univ. of Maryland.

Stewart, R. F., Davidson, E. R. \& Simpson, W. T. (1965). J. Chem. Phys. 42, 3175-3187.

Yoshida, A., Morita, M. \& Ogawa, S. (1973a). J. Pharm. Soc. Japan, 93, 508-518.

Yoshida, A., Morita, M. \& Ogawa, S. (1973b). J. Pharm. Soc. Japan, 93, 519-528.

Acta Cryst. (1976). B32, 1850

\title{
The Crystal Structure of an Orthorhombic Form of Adenosine-5'-monophosphate
}

\author{
By S. NeIDle, W. KüHLbRANDT* AND A. AchaRI \\ Department of Biophysics, King's College, 26-29 Drury Lane, London, WC2B 5RL, England
}

(Received 19 November 1975; accepted 30 December 1975)

\begin{abstract}
Adenosine-5'-phosphate monohydrate was crystallized in the orthorhombic space group $P 2_{1} 2_{1} 2_{1}$, with $a=22.997$ (2), $b=9.406$ (1), $c=6.599$ (1) $\AA, Z=4$. The structure was solved by direct methods and refined to a final $R_{w}$ of 0.0639 for 1320 significant reflexions measured on an automatic diffractometer. The conformation of the molecule differs significantly from that previously reported for the monoclinic monohydrate [Kraut \& Jensen, Acta Cryst. (1963), 16, 79-88]. The sugar conformation, for example, is here $\mathrm{C}(2)^{\prime}$-endo, and the glycosidic torsion angle has altered by almost $50^{\circ}$.
\end{abstract}

\section{Introduction}

The structure of adenosine- $5^{\prime}$-monophosphate (5'AMP) was first determined by Kraut \& Jensen (1963), who crystallized it in the monoclinic space group $P 2_{1}$.

* Present address: The Free University of Berlin.
The results of this and other nucleotide structure analyses have been instrumental in furthering knowledge of the structures of the nucleic acids (Arnott, 1970). Especially useful and interesting have been the findings that the solid-state conformations of the nucleotides have been found to fall into a small number of discrete classes (Sundaralingam, 1969, 1973). How- 
ever, the degree of conformational flexibility of these molecules has long been a subject of dispute, as has the question of whether their solid-state crystal structures really reflect their solution conformations. Recent NMR studies unfortunately provide conflicting results (Barry, North, Glasel, Williams \& Xavier, 1971; Sarma, Mynott, Hruska \& Wood, 1973). Conformational energy calculations (Thornton \& Bayley, 1975) suggest that $5^{\prime}-\mathrm{AMP}$, at least, is relatively flexible, with a small number of preferred conformations. The Kraut $\&$ Jensen structure corresponds to a very low-energy (i.e. highly favoured) state.

It is therefore of some interest to examine the conformation of 5 -AMP in a different crystallographic environment, possibly providing an indication of the conformational rigidity of the molecule. As part of our programme of studies on nucleic acid constituents we have obtained crystals of an orthorhombic form, which we have subjected to a full single-crystal analysis.

\section{Experimental}

Colourless, long thin laths of $5^{\prime}$-AMP (Sigma Chemical Co.) were obtained by slow evaporation from aqueous solution. They showed parallel extinction under the polarizing microscope. Photographs revealed the crystals to have orthorhombic symmetry. Systematic absences $h 00,0 k 0$ and $00 l$ with $h, k$ and $l=$ $2 n+1$ respectively, uniquely identified the space group as $P 22_{1} 2_{1} 2_{1}$. Cell dimensions were obtained from leastsquares refinement of $2 \theta$ values measured on a diffractometer.

\section{Crystal data}

$\mathrm{C}_{10} \mathrm{H}_{14} \mathrm{~N}_{5} \mathrm{O}_{7} \mathrm{P} . \mathrm{H}_{2} \mathrm{O}$, F.W. 365.23. Orthorhombic needles, elongated along b. $a=22.997$ (2), $b=9.406$ (1), $c=6.599$ (1) $\AA, V=1427.43 \AA^{3}, D_{o}=1.73$ (2) (by flotation), $D_{c}=1.711 \mathrm{~g} \mathrm{~cm}^{-3}$ for $Z=4$. $F(000)=756, \mu=$ $21.17 \mathrm{~cm}^{-1}$ for $\mathrm{Cu} K \alpha$ radiation $\left(\lambda_{K \alpha}=1.54178 \AA\right)$. Space group $P 22_{1} 2_{1}$ (No. 19).

Intensities were collected on a Siemens automatic four-circle diffractometer. 1549 unique reflexions were measured with a $\theta-2 \theta$ scan technique, to a limit of $70^{\circ}$ in $\theta$, and $\mathrm{Ni}$-filtered $\mathrm{Cu} K \alpha$ radiation. Of these 1320 were considered to have counts significantly above background, with $I>2 \cdot 5 \sigma(I)$. An absorption correction was not applied in view of the small size of the crystal $(0.20 \times 0.05 \times 0.02 \mathrm{~mm})$.

\section{Structure determination and refinement}

The structure was solved by direct methods with a multisolution tangent formula technique programmed by Dr G. M. Sheldrick. The positions of all 24 nonhydrogen atoms (including a water $\mathrm{O}$ atom) were clearly revealed in the most consistent $E$ map. Refinement was by full-matrix least squares, $\sum w\left(F_{o}^{2}-F_{c}^{2} / k^{2}\right)$ being minimized; weights $w$ were chosen as $1 / \sigma^{2}\left(F_{o}^{2}\right)$ from counting statistics, and $k$ was a scale factor. The positional coordinates of all $\mathrm{H}$ atoms except those attached to the water molecule and to a phosphate $\mathrm{O}$ atom, were deduced from difference syntheses calculated during the later stages of refinement. These missing $\mathrm{H}$ atoms were not located at any stage of the analysis. Convergence of refinement was achieved with

Table 1. Final positional $\left(\times 10^{4}\right)$ and anisotropic $\left(U_{i j}\right)$ thermal parameters $\left(\times 10^{3}\right)$ for the non-hydrogen atoms

Estimated standard deviations are given in parentheses.

\begin{tabular}{|c|c|c|c|c|c|c|c|c|c|}
\hline & $x$ & $y$ & $z$ & $U_{11}$ & $U_{22}$ & $U_{33}$ & $U_{23}$ & $U_{13}$ & $U_{12}$ \\
\hline$C(1)^{\prime}$ & $1867(3)$ & $1117(8)$ & $7401(16)$ & $28(4)$ & $9(4)$ & $41(5)$ & $1(4)$ & $-4(4)$ & $0(3)$ \\
\hline$C(2)$ & 3419 (4) & $3729(10)$ & $7416(18)$ & $27(4)$ & $36(5)$ & $46(6)$ & $-3(6)$ & $5(5)$ & $-2(3)$ \\
\hline $\mathrm{C}(2)^{\prime}$ & $1415(4)$ & $537(9)$ & 8895 (14) & $37(5)$ & $12(4)$ & $31(5)$ & $-7(4)$ & $1(4)$ & 1 (4) \\
\hline $\mathrm{C}(3)^{\prime}$ & $1170(4)$ & $-718(8)$ & 7704 (14) & 31 (4) & 13 (4) & $29(5)$ & $1(4)$ & $-4(4)$ & $-3(3)$ \\
\hline C(4) & 2469 (3) & 3341 (6) & 7523 (15) & $25(4)$ & 21 (4) & $28(4)$ & $-2(4)$ & $-4(4)$ & $-3(3)$ \\
\hline$C(4)^{\prime}$ & $1226(4)$ & $-279(9)$ & 5445 (14) & $38(5)$ & $10(4)$ & $31(5)$ & $-4(4)$ & $-3(4)$ & $-4(3)$ \\
\hline C(5) & 2328 (3) & $4835(8)$ & $7554(15)$ & 30 (4) & $9(4)$ & $32(5)$ & $3(4)$ & $1(4)$ & $-2(3)$ \\
\hline$C(5)^{\prime}$ & $685(4)$ & $325(10)$ & 4498 (18) & 42 (5) & $21(5)$ & $50(6)$ & $-15(5)$ & $-10(5)$ & 1 (4) \\
\hline C(6) & 2797 (3) & $5765(9)$ & 7551 (14) & 33 (4) & $29(5)$ & $19(4)$ & $-3(5)$ & $-3(4)$ & $-15(4)$ \\
\hline$C(8)$ & $1516(3)$ & $3722(8)$ & $7606(16)$ & $23(4)$ & $19(4)$ & $39(5)$ & $1(4)$ & $-2(4)$ & $-2(3)$ \\
\hline$N(1)$ & 3334 (3) & $5187(7)$ & $7520(14)$ & $24(4)$ & $24(4)$ & $47(5)$ & $2(4)$ & $-2(4)$ & $-8(3)$ \\
\hline$N(3)$ & 3004 (3) & $2793(7)$ & $7421(14)$ & $28(3)$ & $19(4)$ & $51(5)$ & $0(4)$ & $2(4)$ & $-2(3)$ \\
\hline$N(6)$ & $2740(4)$ & $7199(7)$ & $7580(16)$ & $43(5)$ & $9(4)$ & $51(5)$ & $1(4)$ & $-1(5)$ & $-10(3)$ \\
\hline$N(7)$ & $1738(3)$ & $5023(6)$ & $7605(14)$ & $34(4)$ & $6(3)$ & $44(5)$ & $-2(4)$ & $-4(4)$ & $-3(3)$ \\
\hline$N(9)$ & $1947(3)$ & $2685(6)$ & 7557 (13) & $27(3)$ & $10(3)$ & $33(4)$ & $1(3)$ & $2(4)$ & $0(3)$ \\
\hline$O(1)$ & $185(3)$ & 4059 (7) & $5767(14)$ & $53(4)$ & $29(4)$ & $81(6)$ & $-22(5)$ & $2(5)$ & $5(3)$ \\
\hline$O(1)^{\prime}$ & $1688(3)$ & $784(6)$ & 5415 (9) & $46(3)$ & $22(3)$ & $26(3)$ & $-3(3)$ & $4(3)$ & $-12(3)$ \\
\hline $\mathrm{O}(2)$ & $770(3)$ & $3217(6)$ & $2602(14)$ & $37(3)$ & $24(3)$ & $68(5)$ & $2(4)$ & $3(4)$ & $-10(3)$ \\
\hline $\mathrm{O}(2)^{\prime}$ & $1652(3)$ & $195(6)$ & $10765(11)$ & $56(4)$ & $15(3)$ & $33(3)$ & $-2(3)$ & $-4(4)$ & $-7(3)$ \\
\hline$O(3)$ & $-254(2)$ & $2464(7)$ & 3089 (11) & $24(3)$ & $30(4)$ & $63(5)$ & $12(3)$ & $-1(3)$ & $-8(3)$ \\
\hline$O(3)^{\prime}$ & $1545(3)$ & $-1928(6)$ & 8090 (10) & $54(4)$ & $6(3)$ & $50(4)$ & $-1(3)$ & $-7(3)$ & $5(3)$ \\
\hline$O(5)^{\prime}$ & $523(3)$ & $1634(6)$ & $5546(11)$ & $55(4)$ & $17(3)$ & $38(4)$ & $2(3)$ & $-7(4)$ & $8(3)$ \\
\hline $\mathbf{P}$ & $319(1)$ & $2953(2)$ & $4183(4)$ & $24(1)$ & $17(1)$ & $56(2)$ & $2(1)$ & $-1(1)$ & $-3(1)$ \\
\hline $\mathrm{O}(W)^{* k}$ & $5341(4)$ & $-1851(8)$ & $4223(16)$ & $58(5)$ & $31(4)$ & $77(6)$ & $-6(5)$ & $-8(6)$ & $0(4)$ \\
\hline
\end{tabular}


non-hydrogen positional and anisotropic thermal parameters, and hydrogen positional and isotropic thermal parameters, all varied simultaneously. The final $R_{w}$ was $0.0639\left(R_{w}=\sum w|| F_{o}|-| F_{c}|| \sum w\left|F_{o}\right|\right) ; R$ was 0.0652 . The final parameters are listed in Tables 1 and $2 . *$

Scattering factors and anomalous dispersion corrections were taken from International Tables for X-ray Crystallography (1974). The signs of the dispersion corrections were taken by reference to the known D-ribose absolute configuration of the molecule; the positional parameters all correspond to the correct

* A list of structure factors has been deposited with the British Library Lending Division as Supplementary Publication No. SUP 31580 (9 pp.). Copies may be obtained through The Executive Secretary, International Union of Crystallography, 13 White Friars, Chester CHI 1NZ, England.
Table 2. Final positional $\left(\times 10^{3}\right)$ and isotropic $(U)$ thermal parameters $\left(\times 10^{2}\right)$ for the hydrogen atoms

Estimated standard deviations are in parentheses. In each case the non-hydrogen atom to which each hydrogen atom is bonded, is shown.

The average $\mathrm{X}-\mathrm{H}$ distance is 1.00 (14) $\AA$.

$\begin{array}{lrcrc} & x & y & z & U \\ \mathrm{H}(1)(\mathrm{N} 1) & 373(4) & 538(10) & 766(18) & 5(3) \\ \mathrm{H}(2)(\mathrm{C} 2) & 379(4) & 322(9) & 734(16) & 4(2) \\ \mathrm{H}(6)(\mathrm{N} 6) & 233(3) & 753(8) & 750(16) & 2(2) \\ \mathrm{H}(6)^{\prime}(\mathrm{N} 6) & 304(4) & 751(9) & 774(15) & 2(2) \\ \mathrm{H}(8)(\mathrm{C} 6) & 109(3) & 354(7) & 757(13) & 1(2) \\ \mathrm{H}(1)^{\prime}\left(\mathrm{C} 1^{\prime}\right) & 233(3) & 76(7) & 759(13) & 1(2) \\ \mathrm{H}(2)^{\prime}\left(\mathrm{C} 2^{\prime}\right) & 109(3) & 120(9) & 900(15) & 3(2) \\ \mathrm{H}(2)^{\prime \prime}\left(\mathrm{O} 2^{\prime}\right) & 211(4) & 14(11) & 1075(19) & 6(3) \\ \mathrm{H}(3)^{\prime}\left(\mathrm{C} 3^{\prime}\right) & 70(3) & -85(8) & 789(13) & 2(2) \\ \mathrm{H}(3)^{\prime \prime}\left(\mathrm{O}^{\prime}\right) & 159(4) & -183(9) & 680(16) & 6(4) \\ \mathrm{H}(4)^{\prime}\left(\mathrm{C}^{\prime}\right) & 136(5) & -109(13) & 439(20) & 8(4) \\ \mathrm{H}(5)^{\prime}\left(\mathrm{C} 5^{\prime}\right) & 23(4) & -14(10) & 470(15) & 5(3) \\ \mathrm{H}(5)^{\prime \prime}\left(\mathrm{C} 5^{\prime}\right) & 79(4) & 39(9) & 293(15) & 3(2)\end{array}$

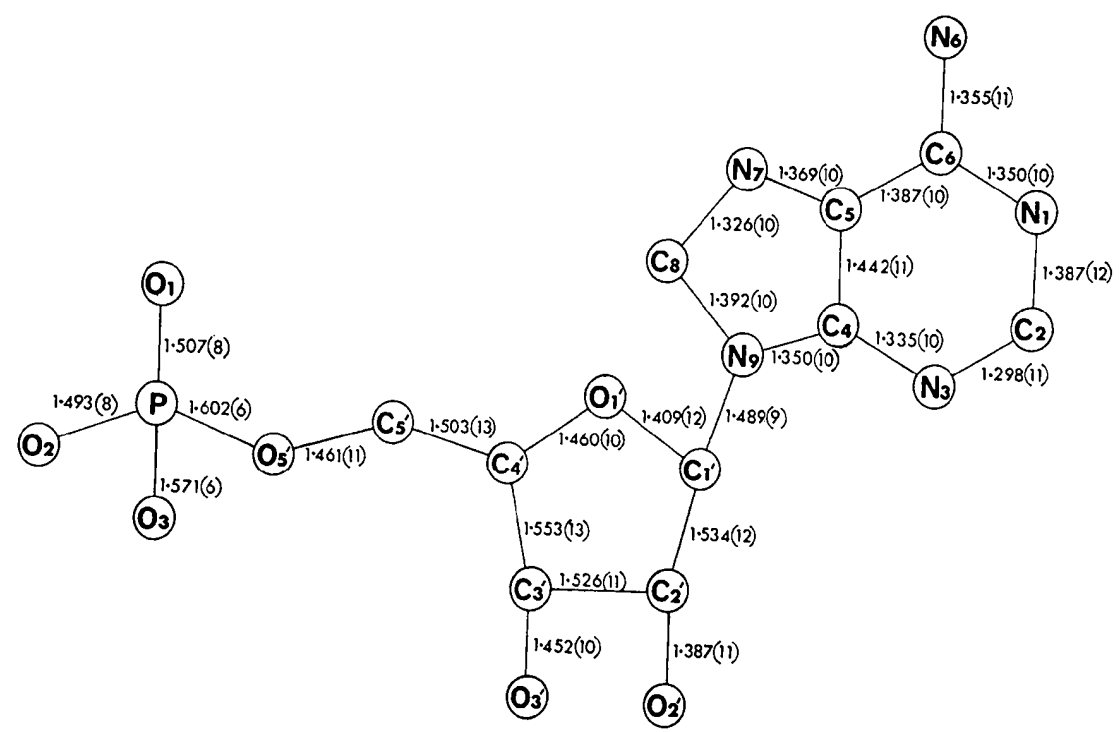

Fig. 1. Intramolecular bonded distances in $\AA$. Estimated standard deviations are given in parentheses.

$$
\begin{array}{ll}
\mathbf{O}_{1}-\mathbf{P}-\mathbf{O}_{3} & 110 \cdot 5(4) \\
\mathbf{O}_{2}-\mathbf{P}-\mathbf{O}_{5} & 108 \cdot 5(4)
\end{array}
$$

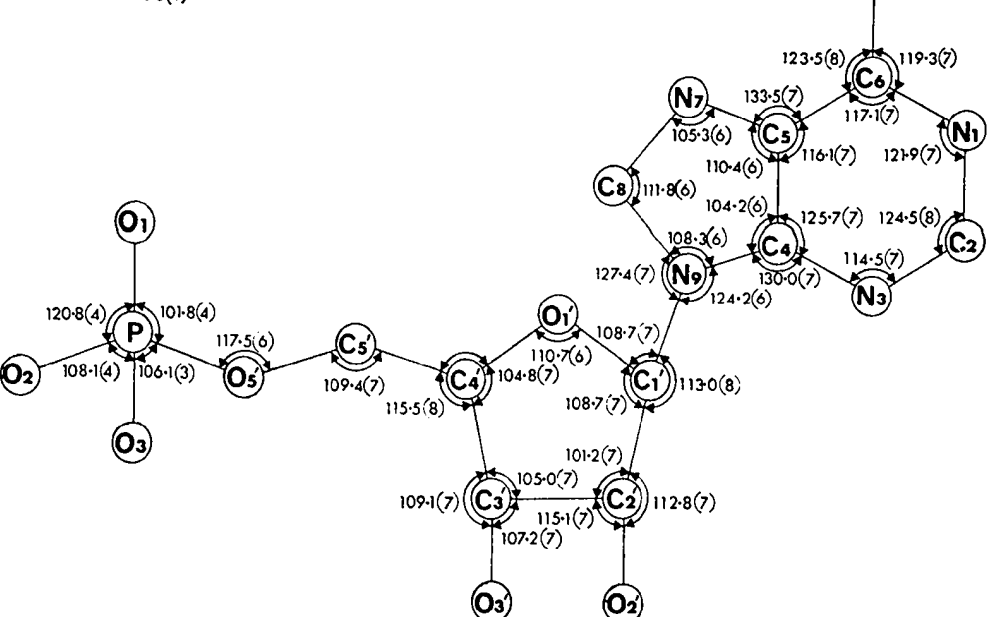

Fig. 2. Valence angles, in degrees, with estimated standard deviations in parentheses. 
configuration. The calculations were performed with a set of programs written by Dr G. M. Sheldrick, and implemented on a CDC 7600 computer.

\section{Discussion}

\section{The molecular structure - bond lengths and angles}

The analysis has shown that $5^{\prime}$-AMP exists in the orthorhombic form as a zwitterion with protonation at $\mathrm{N}(1)$; the monoclinic form has the same distribution

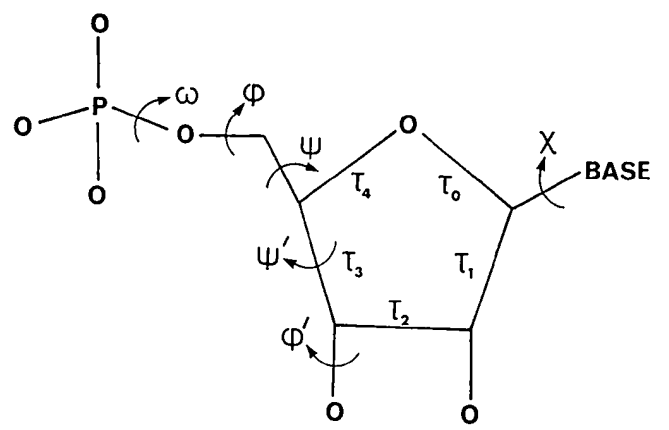

Fig. 3. The conformational angles of a nucleotide unit. These are considered positive for a right-handed clockwise rotation (Sundaralingam, 1969). Angles $\omega, \varphi^{\prime}$ are not applicable to a monomer, i.e. a mononucleotide.

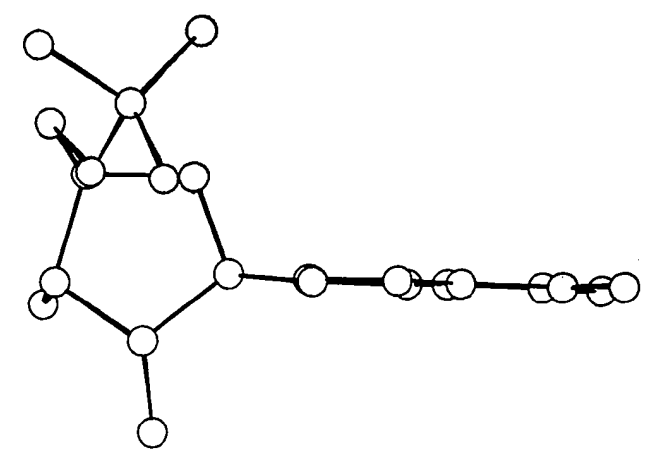

(a)

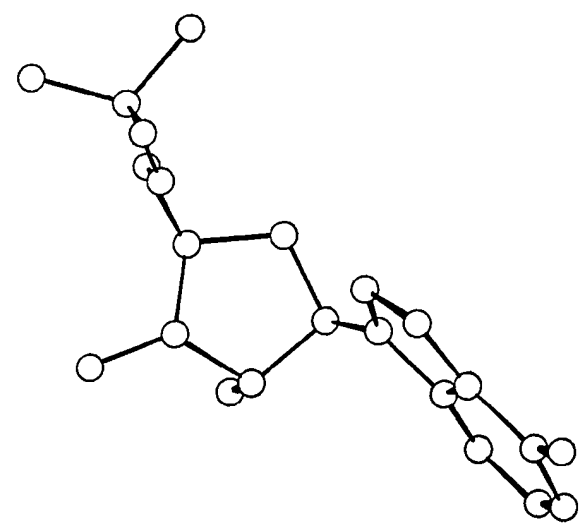

(b)

Fig. 4. Views of $(a)$ orthorhombic 5 -AMP and $(b)$ monoclinic $5^{\prime}$-AMP, perpendicular to the $\mathrm{C}(1)^{\prime}-\mathrm{O}(1)^{\prime}-\mathrm{C}(5)^{\prime}$ sugar plane. of charge, with a negative charge presumably located on a phosphate $\mathrm{O}$ atom. Intramolecular bond lengths and angles for orthorhombic 5'-AMP are shown in Figs. 1 and 2. The values found compare well with those reported for monoclinic 5'-AMP, although there are a few significant bond length differences - these are detailed below.

Average bond lengths and angles for the adenine base have been reported in a survey (Voet \& Rich, 1970). The geometry of the adenine in orthorhombic $5^{\prime}$-AMP is comparable with these averages; as noted elsewhere (Saenger, 1973) protonation at N(1) has induced slight differences between the zwitterion and neutral molecules. $\mathrm{N}(1)-\mathrm{C}(2)$, particularly, is lengthened in the ionic form, and the angle at $N(1)$ is slightly widened. The anomalously long $\mathrm{C}(4)-\mathrm{C}(5)$ recorded here $(1.442 \AA)$, compared with averages of 1.365 for neutral and $1.392 \AA$ for protonated molecules, does not fit into this pattern and cannot easily be explained. $\mathrm{C}(5)-\mathrm{C}(6)$, on the other hand, is much shorter than in monoclinic 5'-AMP (1.387 compared to $1.448 \AA)$ and conforms with the tabulated averages. The adenine ring is planar within experimental error (Table 3).

\section{Table 3. Least-squares planes}

Atoms marked $\left(^{*}\right)$ have been excluded from the calculation of the plane. Deviations from the planes are in $\AA$.

Adenine ring

$\mathrm{N}(1) 0.022, \mathrm{C}(2)-0.012, \mathrm{~N}(3)-0.015, \mathrm{C}(4) 0.010$,

$\mathrm{C}(5)-0.001, \mathrm{C}(6)-0.002, \mathrm{~N}(6)-0.019, \mathrm{~N}(7)-0.012$, $\mathrm{C}(8) 0.001, \mathrm{~N}(9) 0.015$

Sugar ring

$\mathrm{C}(1)^{\prime} 0 \cdot 000, \mathrm{C}(2)^{\prime} 0 \cdot 359^{*}, \mathrm{C}(3)^{\prime}-0 \cdot 146^{*}, \mathrm{C}(4)^{\prime} 0 \cdot 000$, $\mathrm{O}(1)^{\prime} 0.000$

The equations for the least-squares planes are in the form:

$$
p x+q y+r z=s \text {. }
$$

$\begin{array}{ccccc} & p & \boldsymbol{q} & \boldsymbol{r} & \boldsymbol{s} \\ \text { Adenine ring } & 0.025 & -0.022 & 0.999 & 5.028\end{array}$

$\begin{array}{lllll}\text { Sugar ring } & 0.685 & -0.727 & -0.042 & 1.974\end{array}$

The geometry of the ribose sugar ring conforms well with expected values (Saenger, 1973), although the two hydroxyl bonds do differ more than might be expected from a reported mean of $1.41 \AA$. The commonly observed finding of $\mathrm{O}(1)^{\prime}-\mathrm{C}(4)^{\prime}$ longer than $\mathrm{O}(1)^{\prime}-\mathrm{C}(1)^{\prime}$ is seen here.

Although no proton was found on any of the phosphate $\mathrm{O}$ atoms, its probable location was readily deduced. $\mathrm{P}-\mathrm{O}(3)$ is undoubtedly a double bond. Since $\mathrm{O}(2)$ has a close contact $(2 \cdot 5 \AA)$ with protonated $\mathrm{N}(1)$, it is likely that it carries a negative charge, rather than a proton, which must therefore be attached to $O(1)$.

\section{Molecular conformation}

The conformational angles used in this discussion are defined in Fig. 3. These are discussed in some detail by, for example, Sussman, Seeman, Kim \& Berman (1972) and Sundaralingam (1969). Table 4 gives the 
values found for the angles, both from this analysis and for some other related nucleotides. It is apparent that the two 5 -AMP structures exhibit markedly different conformations in all parts of the molecules. These differences are shown in Figs. 4 and 5, which particularly highlight the nearly $50^{\circ}$ difference in the $\mathrm{O}\left(1^{\prime}\right)-\mathrm{C}\left(1^{\prime}\right)-\mathrm{N}(9)-\mathrm{C}(8)(\chi)$ glycosidic torsion angle. The monoclinic form has a syn conformation, and the orthorhombic may be said to be anti (although only just); however, although the $\chi$ value for the former falls well within ranges of values for many purine nucleotides, that for the latter does not (Sundaralingam, 1969).

This is probably connected with the $\mathrm{C}\left(2^{\prime}\right)$-endo sugar conformation observed here, which contrasts with the $\mathrm{C}\left(3^{\prime}\right)$-endo of the monoclinic form. This difference is shown in Fig. 5. The observed ribose torsion angles and out-of-plane deviations (Table 3) are typical of $\mathrm{C}\left(2^{\prime}\right)$-endo puckering. The results of the conformational energy calculations of Thornton \& Bayley (1975) are given in detail for a $\mathrm{C}\left(3^{\prime}\right)$-endo sugar only; however, these authors do suggest that a $\mathrm{C}\left(2^{\prime}\right)$-endo puckering would prefer a $\chi$ angle of about $60^{\circ}$, with preference for the syn state. This is indeed roughly what we find.

These two sugar conformations are encountered equally commonly among purine and pyrimidine nucleosides and nucleotides. However, a C (2')-endo adenylyl sugar is quite rare. Examples of its occurrence illustrate well the supposition that nucleotides are relatively flexible, and can adopt differing conformations without having to overcome a large energy barrier. Thus, of the two independent molecules in the crystal structure of adenosine triphosphate (Kennard et al., 1971), one has a $\mathrm{C}\left(2^{\prime}\right)$-endo sugar, and the other a $\mathrm{C}\left(3^{\prime}\right)$-endo. The recently-reported structures of two dinucleoside phosphate-drug complexes show a $\mathrm{C}\left(2^{\prime}\right)$ endo adenylyl sugar, in contrast to the $\mathrm{C}\left(3^{\prime}\right)$-endo of the uncomplexed dinucleoside phosphates (Seeman, Day \& Rich, 1975; Tsai, Jain \& Sobell, 1975). It seems that, for drug interaction to occur, this conformational change is needed.

\section{Intermolecular packing}

Figs. 6 and 7 show two views of the crystal structure, which consists of chains of 5'-AMP molecules linked
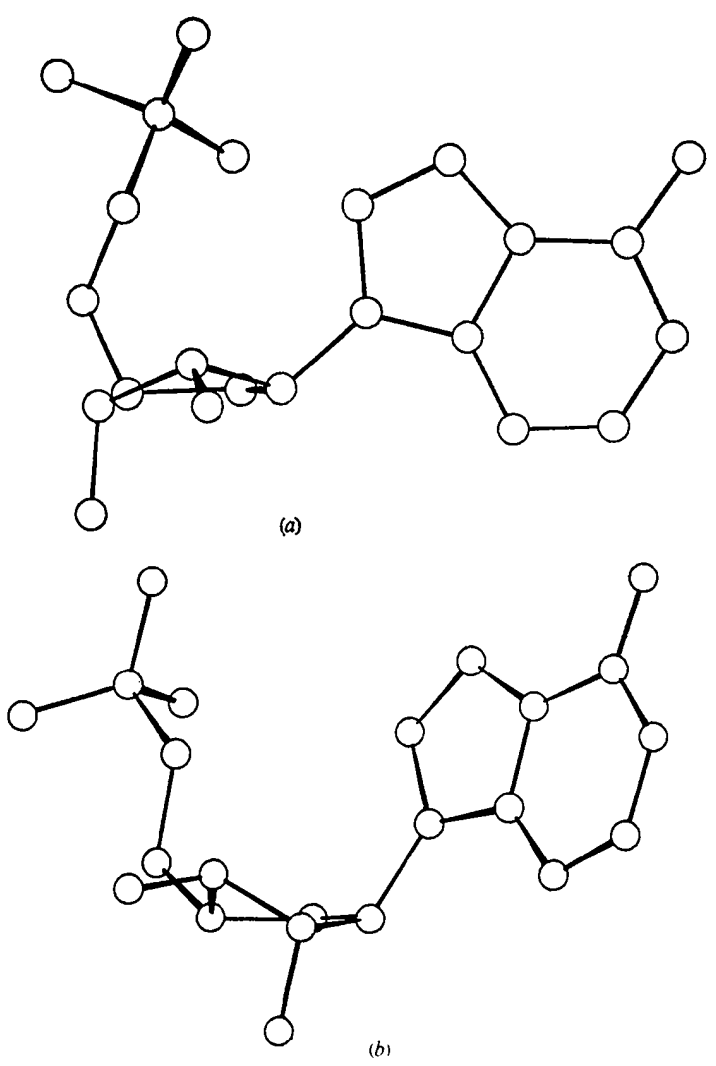

Fig. 5. (a), (b), as in Fig. 4, but now viewed along the $\mathrm{C}(1)^{\prime}-\mathrm{O}(1)^{\prime}-\mathrm{C}(5)^{\prime}$ sugar plane.

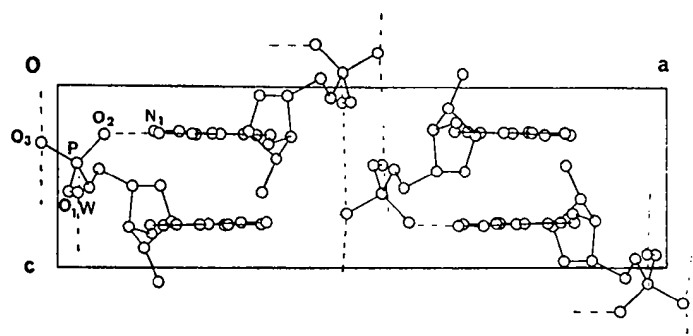

Fig. 6. The $b$-axis projection of the crystal structure; dashed lines represent hydrogen bonds.

Table 4. Some nucleotide and polynucleotide conformations, torsion angles are in degrees

\begin{tabular}{|c|c|c|c|c|c|c|c|c|c|c|}
\hline & $\chi$ & $\varphi$ & $\psi$ & $\psi^{\prime}$ & $\tau_{0}$ & $\tau_{1}$ & $\tau_{2}$ & $\tau_{3}$ & $\tau_{4}$ & Sugar pucker \\
\hline This study & $72 \cdot 5$ & $137 \cdot 3$ & $62 \cdot 3$ & $-32 \cdot 3$ & $-14 \cdot 2$ & $27 \cdot 8$ & $-30 \cdot 2$ & $23 \cdot 3$ & $-5 \cdot 8$ & $\mathrm{C}(2)^{\prime}$-endo \\
\hline ic $5^{\prime}-\mathrm{AMP}(a)$ & $25 \cdot 7$ & $177 \cdot 2$ & $40 \cdot 0$ & $74 \cdot 8$ & 4. & $-29 \cdot 8$ & $42 \cdot 3$ & -40 & $22 \cdot 8$ & endo \\
\hline $3^{\prime}-\operatorname{AMP}(a)$ & $3 \cdot 8$ & $149 \cdot 5$ & $171 \cdot 2$ & $83 \cdot 8$ & $-3 \cdot 4$ & $-19 \cdot 1$ & $34 \cdot 6$ & $-37 \cdot 6$ & $25 \cdot 6$ & $C(3)^{\prime}$-endo \\
\hline $\begin{array}{l}\text { Adenylyl- }-3^{\prime}, 5^{\prime} \text {-uridine }(b) \\
\text { (adenylyl group only) } \\
\text { Adenylyl- } 2^{\prime}, 5^{\prime} \text {-uridine }(a)\end{array}$ & $3 \cdot 5$ & 173 & 57 & - & 一 & - & - & - & - & $\mathrm{C}(3)^{\prime}$-endo \\
\hline $\begin{array}{l}\text { (adenylyl group only) } \\
\text { B-DNA (c) } \\
\text { RNA-11 }(d)\end{array}$ & $\begin{array}{l}54 \cdot 6 \\
66 \\
14\end{array}$ & $\begin{array}{l}2 \overline{13} \\
180\end{array}$ & $\begin{array}{l}45 \cdot 3 \\
36 \\
48\end{array}$ & $\begin{array}{l}148 \cdot 4 \\
156 \\
83\end{array}$ & $\begin{array}{c}-30 \cdot 5 \\
-4 \\
3\end{array}$ & $\begin{array}{l}43 \cdot 5 \\
25 \\
126\end{array}$ & $\begin{array}{l}-37 \cdot 8 \\
-35 \\
37\end{array}$ & $\begin{array}{l}20 \cdot 2 \\
33 \\
-36\end{array}$ & $\begin{array}{c}6 \cdot 1 \\
-19 \\
21\end{array}$ & $\begin{array}{l}\mathrm{C}(2)^{\prime}-\text {-endo } \\
\mathrm{C}(2)^{\prime}-\text { endo } \\
\mathrm{C}(3)^{\prime} \text {-endo }\end{array}$ \\
\hline
\end{tabular}

(a) Values have been taken from the compilation of Sundaralingam (1969). (b) Day, Seeman, Rosenberg \& Rich (1973). The mean values for the two independent molecules are given. The torsion angles for the sugar residues are not reported. $(c)$ Arnott $\&$ Hukins (1972). (d) Arnott, Hukins \& Dover (1972). 


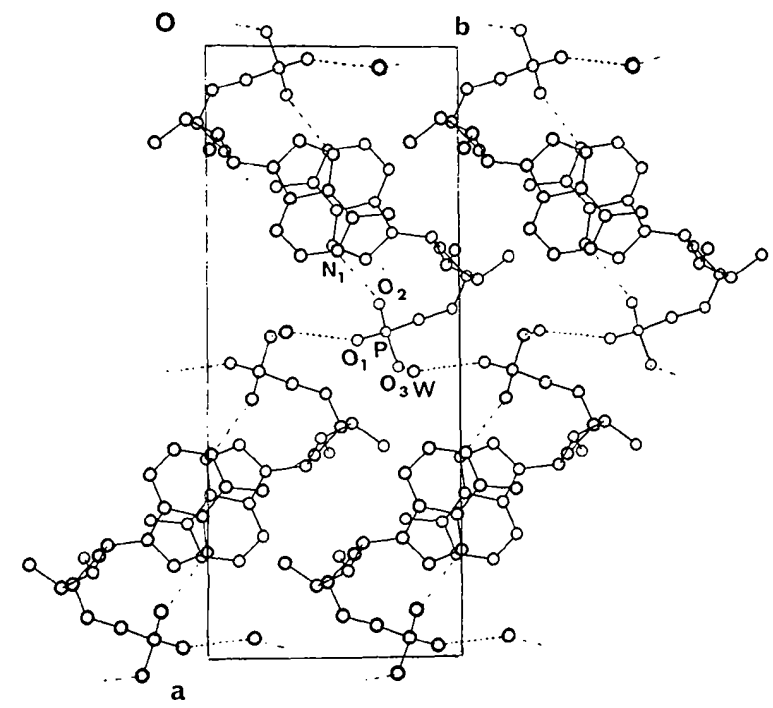

Fig. 7. The $c$-axis projection of the crystal structure.

together by strong hydrogen bonds to water molecules. These chains extend in both the $\mathbf{b}$ and $\mathbf{c}$ directions. The hydrogen bonds are from phosphate $\mathrm{O}$ atoms to the water $\mathrm{O} ; \mathrm{O}(1) \cdots \mathrm{O}(W)$ is 2.651 and $\mathrm{O}(3) \cdots \mathrm{O}(W)$ $2.623 \AA$. There is also a very short (Donohue, 1969; Fuller, 1959) N(1) . . O (2) interaction of $2.550 \AA$, involving $c$-axis screw-related molecules (Fig. 7). The adenine bases are nearly parallel both to each other and to a, some stacking being evident, and with a mean inter-base spacing of about $3.5 \AA$. As has been pointed out (Bugg, Thomas, Sundaralingam \& Rao, 1971), partial base overlap is usual for this class of compound.

It is not surprising, in view of the conformational differences, that there are considerable differences in the packing modes of orthorhombic and monoclinic 5 -AMP in spite of their both crystallizing with one water molecule per nucleotide. For example, in the latter crystal structure, only two of the three phosphate $\mathrm{O}$ atoms participate in hydrogen bonding, whereas the sugar hydroxyl $\mathrm{O}\left(2^{\prime}\right)$ and $\mathrm{O}\left(3^{\prime}\right)$ do.
We thank the Cancer Research Campaign and the Lawson Tait Trust for support, the Crystallography Institute of the Free University of Berlin for the data collection facilities, Drs $H$. J. Hecht and P. Beinhardt for assistance in their use and Dr E. G. Richards for various useful discussions on this structure.

\section{References}

Arnott, S. (1970). Progr. Biophys. Mol. Biol. 21, 265-319. Arnot,, S. \& Hukins, D. W. L. (1972). Biochem. Biophys. Res. Commun. 47, 1504-1509.

Arnott, S., Hukins, D. W. L. \& Dover, S. D. (1972). Biochem. Biophys. Res. Commun. 48, 1392-1398.

Barry, C. D., North, A. C. T., Glasel, J. A., Williams, R. J. P. \& Xavier, A. V. (1971). Nature, Lond. 232, 236245.

Bugg, C. E., Thomas, J. M., Sundaralingam, M. \& Rao, S. T. (1971). Biopolymers, 10, 175-219.

Day, R. O., Seeman, N. C., RosenberG, J. M. \& Rich, A. (1973). Proc. Natl. Acad. Sci. U.S. 70, 849-853.

Donohue, J. (1969). Structural Chemistry and Molecular Biology, edited by A. Rich \& N. DAvidson, pp. 443-465. San Francisco: Freeman.

Fuller, W. (1959). J. Phys. Chem. 63, 1705-1717.

International Tables for X-ray Crystallography (1974). Vol. IV, pp. 99, 149. Birmingham: Kynoch Press.

Kennard, O., IsaAcs, N. W., Motherwell, W. D. S., Coppola, J. C., Wampler, D. L., Larson, A. C. \& Watson, D. G. (1971). Proc. Roy. Soc. A 325, 401-436.

Kraut, J. \& Jensen, L. H. (1963). Acta Cryst. 16, 79-88.

SaEnger, W. (1973). Angew. Chem. Int. Ed. 12, 591-601.

Sarma, R. H., Mynott, R. J., Hruska, F. E. \& Wood, D. J. (1973). Canad. J. Chem. 51, 1843-1851.

SeEman, N. C., Day, R. O. \& Rich, A. (1975). Nature, Lond. 253, 324-326.

Sundaralingam, M. (1969). Biopolymers, 7, 821-860.

SundaralingaM, M. (1973). Jerusalem Symp. Quantum. Chem. Biochem. 5, 417-456.

Sussman, J. L., Seeman, N. C., Kim, S. H. \& Berman, H. M. (1972). J. Mol. Biol. 66, 403-421.

Thornton, J. M. \& BAyley, P. M. (1975). Biochem. J. 149, 585-596.

Tsai, C.-C., Jain, S. C. \& Sobell, H. M. (1975). Proc. Natl. Acad. Sci. U.S. 72, 628-632.

Voet, D. \& Rich, A. (1970). Progr. Nucl. Acid. Res. Mol. Biol. 10, 183-265. 